\title{
Study of the influence of alcohols addition to gasoline on the distillation curve, and vapor pressure
}

\author{
Irina NIŢĂ, ${ }^{1}$ Elis GEACAI, ${ }^{2}$ Sibel OSMAN* ${ }^{1}$ and Olga IULIAN ${ }^{2}$ \\ ${ }^{1}$ Department of Chemistry and Chemical Engineering, Ovidius University of Constanta, Bd. Mamaia 124, 900521, \\ Constanta, Romania \\ ${ }^{2}$ Department of Inorganic Chemistry, Physical Chemistry and Electrochemistry, "Politehnica” University of \\ Bucharest, Calea Grivitei 132, 010737, Bucharest, Romania
}

\begin{abstract}
The properties of gasoline change as a result of blending with an alcohol. The aim of this paper is to report new experimental data on distillation curve and Reid vapor pressure of pseudo-binary blends of a catalytic reforming gasoline with ethanol, $i$-propanol and $n$-butanol, respectively. Gasoline blend with ethanol was used as reference for discussing properties of isopropanol and respectively, $n$-butanol blends with gasoline. The main conclusion is that alcohol addition to gasoline affects the relevant characteristics of the blend that influence engine operation. Gasoline $+i$-propanol blends have intermediate behavior between gasoline+ethanol and gasoline $+n$-butanol blends.
\end{abstract}

Keywords: gasoline, bioalcohol, distillation curve, Reid vapor pressure, volatility.

\section{Introduction}

Recently, there has been growing interest in gasoline+alcohols blends as a results of the necessity to diversify fuels used in transport sector, with renewable and low-polluting fuels. Gasoline+ethanol blends are commonly used in transportation, in order to reduce environment pollution and the dependency on the fossil fuels. Besides ethanol, propanol and butanol that can be obtained from biomass [1-5], have raised interest as possible gasoline substitutes. The addition of an alcohol to gasoline changes the composition of the resulting fuel, affecting important properties for the combustion process [6]. The influence of ethanol addition to gasoline have been extensively studied [6-12]. An important change of the shape of the distillation curve determined by the addition of ethanol to gasoline was reported [7, 8]. The addition of ethanol to gasoline, initially elevates the vapor pressure of the blend, and then lowers it with the increasing alcohol content [13]. Fewer studies have been presented in the literature on the properties of gasoline+butanol blends [14-16]. The same apparition of a plateau on the distillation curve as a result of azeotrope formation, characteristic for gasoline+ethanol blends, was noted for gasoline with butanol blends [15, 17]. A slightly higher Reid vapor pressure than that of the base gasoline, was registered for mixtures of gasoline with reduced $i$-butanol [15] or $t$-butanol content [13].

The properties of gasoline blends with propanol were less investigated, by far. The result of the addition of $i$-propanol to gasoline consisted in the decrease of the initial and final boiling point, and of the vapor pressure [18]. It is found that much of these studies have given little importance to the chemical composition of gasoline. The composition and respectively, the physicochemical properties varies from sample to sample of gasoline. Therefore, a study performed on a particular sample of gasoline cannot be considered typical of gasoline in general [17]. In order to sustain the diversification of the biofuels used as gasoline extenders or additives, a significant knowledge of the properties of these blends is necessary.

The aim of this paper is to report and discuss new experimental data using a well-characterized gasoline by its chemical composition and other properties important in transport, storage and combustion process. A reformate gasoline with 95 RON (Research Octane Number) not containing added oxygenated compounds was selected as base gasoline, taking into account that this gasoline type is a main component of commercial gasoline and represents the main gasoline stream from refinery. Distillation curve and vapor pressure (Reid vapor pressure) measurements of gasoline blends with ethanol, $i$-propanol and $n$-butanol, alcohols that can be obtained from biomass, are reported. The results are compared with previous measurements. The behavior of gasoline with $i$-propanol and gasoline with $n$-butanol blends are compared, taking as reference gasoline with ethanol blends.

\section{Experimental}

\subsection{Materials}

The catalytic reforming gasoline used as base fuel in the study was supplied by a local company and has no oxygen content. The chemical composition of the gasoline determined by chromatography (AC Reformulyzer®M3 chromatograph, $7890 \mathrm{~N}$ type equiped with a flame ionization detector) is shown in Table 1. Ethanol with a purity grade of $99.8 \%$ was purchased from Merck, $i$-propanol with a purity grade of

\footnotetext{
* Corresponding author. E-mail address: sibel_o@yahoo.ro (Sibel Osman)
} 
$99.0 \%$ and $n$-butanol of $99.5 \%$ purity were purchased from Chemical Company, Romania. The main properties of the base gasoline and alcohols utilized in this work are presented in Table 2. Gasoline blends with ethanol, $i$-propanol and $n$-butanol were prepared at room temperature on a volume basis. The experimental uncertainty in volume fractions was estimated to be less than \pm 0.002 . Distillation curve was determined for blends with alcohol volume fractions of $0.1,0.2,0.3$ and 0.4 ; vapor pressure was determined for blends with alcohol volume fractions of $0.05,0.1,0.2,0.3$ and 0.4

Table 1. Chemical composition of catalytic reforming gasoline.

\begin{tabular}{|c|c|c|c|c|c|c|c|}
\hline \multirow{2}{*}{$\begin{array}{c}\text { Carbon } \\
\text { number in the } \\
\text { molecule }\end{array}$} & \multicolumn{6}{|c|}{ Hydrocarbon groups $(\% \mathrm{w} / \mathrm{w})$} & \multirow{2}{*}{$\begin{array}{c}\text { Total } \\
(\% \text { w/w })\end{array}$} \\
\hline & $n$-paraffins & $i$-paraffins & olefins & cycloolefins & naphthenes & aromatics & \\
\hline 5 & 0.99 & 0.80 & 0.06 & - & 0.05 & - & 1.90 \\
\hline 6 & 1.25 & 2.91 & 0.13 & - & 0.14 & 1.41 & 5.84 \\
\hline 7 & 2.27 & 7.94 & 0.38 & 0.03 & 0.33 & 22.88 & 33.83 \\
\hline 8 & 0.65 & 3.21 & 0.17 & - & 0.17 & 28.12 & 32.32 \\
\hline 9 & 0.12 & 0.85 & 0.04 & - & 0.05 & 18.96 & 20.02 \\
\hline 10 & - & 0.05 & 0.06 & - & - & 4.81 & 4.92 \\
\hline 11 & - & - & 0.03 & - & - & - & 0.03 \\
\hline $12+$ & - & - & - & - & 0.22 & 0.92 & 1.14 \\
\hline Total & 5.28 & 15.76 & 0.87 & 0.03 & 0.96 & 77.10 & 100.00 \\
\hline
\end{tabular}

Table 2. Properties of the base gasoline and alcohols.

\begin{tabular}{lccccc}
\hline \multicolumn{1}{c}{ Property } & Testing method & Gasoline & Ethanol & $\boldsymbol{i}$-Propanol & $\boldsymbol{n}$-Butanol \\
\hline Chemical formula & & $\mathrm{C}_{5}$ to $\mathrm{C}_{12}$ & $\mathrm{C}_{2} \mathrm{H}_{5} \mathrm{OH}$ & $\mathrm{C}_{3} \mathrm{H}_{7} \mathrm{OH}$ & $\mathrm{C}_{4} \mathrm{H}_{9} \mathrm{OH}$ \\
Density $\left(\mathrm{g} / \mathrm{cm}^{3}, 20^{\circ} \mathrm{C}\right)$ & ASTM D4052 & 0.7919 & 0.8034 & 0.7851 & 0.8102 \\
Viscosity at $40^{\circ} \mathrm{C}(\mathrm{mPa} \cdot \mathrm{s})$ & ASTM D445 & 0.3256 & 0.7233 & 1.0080 & 1.4071 \\
Sulfur $(\mathrm{mg} / \mathrm{kg})$ & ASTM D1266 & 1.11 & - & - & - \\
Oxygen content $(\% \mathrm{w} / \mathrm{w})$ & & 0 & 34.8 & 26.6 & 21.6 \\
Molecular weight $(\mathrm{kg} / \mathrm{kmol})$ & & 105.10 & 46.07 & 60.09 & 74.12 \\
\hline
\end{tabular}

\subsection{Equipments}

Samples of gasoline and gasoline+alcohol blends were distilled in a Herzog OptiDist equipment (PAC, Houston, USA) according to the ASTM D 86. The accuracy of temperature was $\pm 0.01{ }^{\circ} \mathrm{C}$ and volume distillate of $\pm 0.5 \mathrm{~mL}$. Final Boiling Point (FBP) repeatability was $3.3{ }^{\circ} \mathrm{C}$ and reproducibility was $7.1{ }^{\circ} \mathrm{C}$. The Reid vapor pressure was determined with a MINIVAP VPXpert equipment (Grabner Instruments) (range of pressure measurement of $0 \mathrm{k} \mathrm{Pa}$ to $1000 \mathrm{k} \mathrm{Pa}$ ) in accordance with the ASTM D 5191. The sample temperature accuracy was $\pm 0.1{ }^{\circ} \mathrm{C}$, the instrument repeatability $\leq 0.3 \mathrm{k} \mathrm{Pa}\left(37.8{ }^{\circ} \mathrm{C}, 70 \mathrm{k} \mathrm{Pa}\right)$, the reproducibility $\leq 0.7 \mathrm{k} \mathrm{Pa}\left(37.8{ }^{\circ} \mathrm{C}, 70 \mathrm{k} \mathrm{Pa}\right)$ and the standard liquid to vapor ratio was $\mathrm{V} / \mathrm{L}=4.0$.

\section{Results and discussions}

Gasoline volatility is expressed by vapor pressure, distillation curve, and often the drivability index. The evaporative emissions and overall drivability, meaning the performance of the fuel in the spark ignition engine, depend on the volatility properties. The presence of alcohols in gasoline changes the volatility and the octane number of the fuel.

\subsection{Distillation curves}

The distillation curve is one of the most important indicators of the behavior of a fuel represented by complex mixtures. The composition of multicomponent systems like gasoline, and related vapor - liquid equilibrium are controlling factors in distillation [19]. The shape of the distillation curve of gasoline can be related to engine performance and emissions. Frontend volatility correlates with the easiness of cold and hot starting, running-loss emissions, and hot fuel handling problems. Rapid warm-up and smooth running, protection against carburetor icing and hot-stalling as well as good power and acceleration and good short-trip fuel economy depend on mid-range volatility profile. Tail-end volatility controls fuel economy after warm-up, fuel dilution of crankcase oil, volatile organic compound exhaust emissions and engine deposits formation. The distillation curves obtained for gasoline+ethanol, gasoline $+i$-propanol and gasoline $+n$-butanol blends are presented in Figs. 1-3. All the curves have a typical sigmoidal profile, characteristic for liquids with many components $[19,20]$.

Reference points of the distillation curve are the initial boiling point (IBP), final boiling point (FBP) and intermediate points: T10, T50 and T90 (according to ASTM 4814) that represent the temperature at which 10 , 50 and 90 respectively, distilled volume is recovered. Table 3 presents IBPs, FBPs, T10, T50 and T90 parameters values for gasoline and gasoline+ethanol, gasoline $+i$-propanol and gasoline $+n$-butanol blends.

The IBP of $68.2{ }^{\circ} \mathrm{C}$ of the base gasoline is related to the reduced light hydrocarbons content, and the FBP of $186.1{ }^{\circ} \mathrm{C}$ is related to the great amount of heavier hydrocarbons as presented in Table 1. The IBP of gasoline blends with different ethanol contents (Table 3) 
varied slightly in the range of $66-67{ }^{\circ} \mathrm{C}$. A more significant decrease of the IBP in the range of 60.4 to $64.8^{\circ} \mathrm{C}$ was noted for gasoline $+i$-propanol blends. The IBPs of gasoline blends with $n$-butanol were intermediate between the IBP of the blends with $i$ propanol and ethanol, respectively. The FBP of gasoline blends with alcohols decreased slightly compared to FBP of base gasoline.

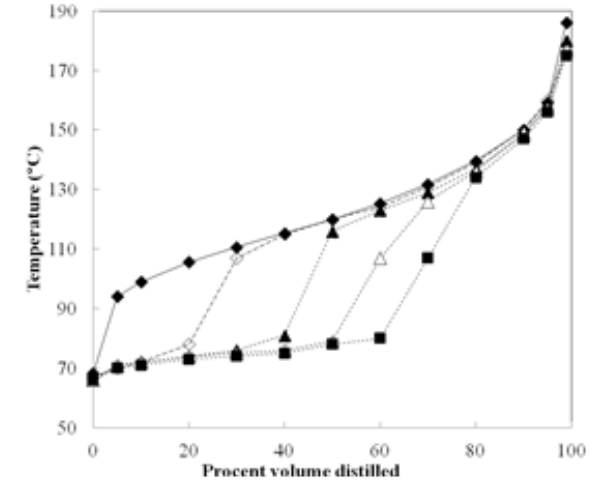

Figure 1. Distillation curves of gasoline+ethanol blends: * $0 \% ; \diamond 10 \% ; \Delta 20 \% ; \Delta 30 \% ; \quad 40 \%$ alcohol content.

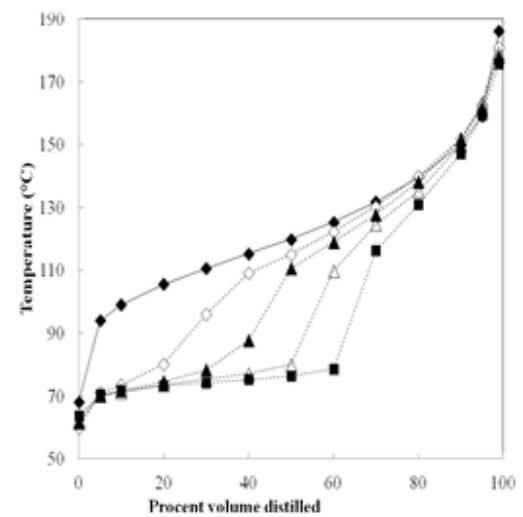

Figure 2. Distillation curves of gasoline $+i$-propanol blends: $0 \% ; \diamond 10 \% ; \Delta 20 \% ; \Delta 30 \%$; $40 \%$ alcohol content.

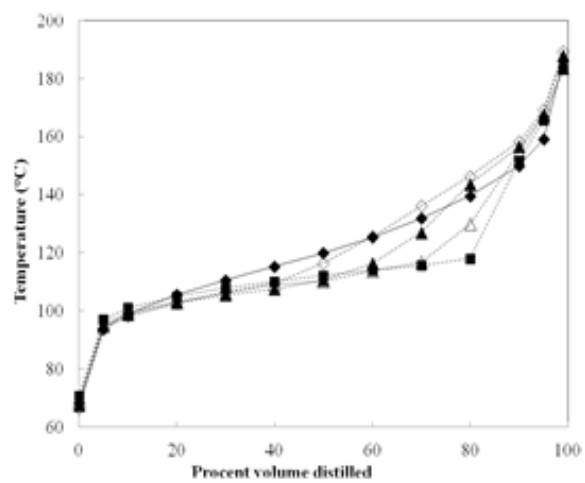

Figure 3. Distillation curves of gasoline $+n$-butanol blends: $0 \% ; \diamond 10 \% ; \Delta 20 \% ; \Delta 30 \% ; \quad 40 \%$ alcohol content.

In the first part of the distillation curves, a depression was registered due to the addition of the alcohols (Figs. 1-3). The depression registered for gasoline blends with ethanol and $i$-propanol, respectively, was approximately similar, but much subtle for butanol blends. The modification of the first part of the distillation curve by the presence of a plateau, was called "azeotropic inflection" by Hadler et al. [21]. It can be explained only partly by azeotropic inflection since some light hydrocarbons form azeotropes with the alcohol, at a temperature lower but very close to the boiling point of the alcohol. Azeotropes form only in that quantity determined by these hydrocarbons' content in gasoline, so when this quantity is over, the next component distilled is the alcohol itself. The length of the plateau increases with the increase of alcohol content of the blend, due to the increased quantity of alcohol added in the gasoline $(10 \% ; 20 \% ; 30 \% ; 40 \%)$ which distilled alone after the azeotrope formation finished. As can be observed from Figs. 1-3, the plateau length is almost the same for gasoline blends containing the same quantity of ethanol or $i$-propanol, and is much larger for gasoline $+n$-butanol blends. This behavior is characteristic for gasoline+alcohol blends [2,8]. The modification of the distillation curve is due to alcohols which form azeotropes with some hydrocarbons from gasoline. Three regions were identified on the distillation curve of gasoline+alcohol blends (Fig.1): a plateau or azeotropic region determined by the presence of minimum boiling azeotropes, a transition region, and a dilution-only region [22].

The volatility of the lighter, medium and heavy fractions of gasoline is affected by alcohol addition. The addition of alcohol to gasoline mostly affects T10, T50 and T90 parameters values of gasoline+ethanol and gasoline $+i$-propanol blends. T10 and T50 parameters values are more influenced by ethanol and $i$-propanol addition to gasoline compared to T90 parameter values. The addition of alcohol to gasoline decreases T10 and T50 parameters values, the decrease being more important for gasoline+ethanol and gasoline $+i$-propanol blends, and less important for gasoline $+n$-butanol blends. The decrease of T10 and T50 parameters values is more important for blends with increased alcohol content. T90 parameters values of alcohol+gasoline blends are oscillating around corresponding value of T90 parameter of the base gasoline. As seen from Figs. $1-3$, T10 parameter is situated in the plateau region of the distillation curve, and T 90 parameter in the dilutiononly region for all the investigated gasoline+alcohol blends. With the increase of alcohol content, T 50 parameter is moving from the dilution-only region, to the plateau region for gasoline+ethanol and gasoline $+i$ propanol blends. In the case of gasoline $+n$-butanol blends, T 50 parameter is situated in the plateau region (90\% gasoline+10\% $n$-butanol blend) or in the transition region $(20 \% \mathrm{v} / \mathrm{v}$ and $30 \% \mathrm{v} / \mathrm{v} n$-butanol in the blend, respectively). An additional parameter to control the evaporation process of gasoline is the Drivability Index (DI). It was proposed first for gasoline blends with ethanol, and then was extended to blends with other oxygenated compounds [23]:

$$
\begin{gathered}
D I=1.5 \times T 10+3.1 \times T 50+1.0 \times T 90+1.33 \times \\
\quad(\text { alcohol volume percent })
\end{gathered}
$$

The DI values decrease with alcohol content increasing (Fig. 4) for blends with up to $30 \% \mathrm{v} / \mathrm{v}$ ethanol or $i$-propanol, and with up to $20 \% \mathrm{v} / \mathrm{v} n$-butanol. The decrease is more important for gasoline+ethanol and gasoline $+i$-propanol blends. DI for gasoline+ethanol and gasoline $+i$-propanol blends varies between 533 and $631{ }^{\circ} \mathrm{C}$. DI for gasoline $+n$-butanol blends varies in the 
range of 630.5 to $660{ }^{\circ} \mathrm{C}$. From the drivability point of view, only ethanol and $i$-propanol are recommended to be added to gasoline.

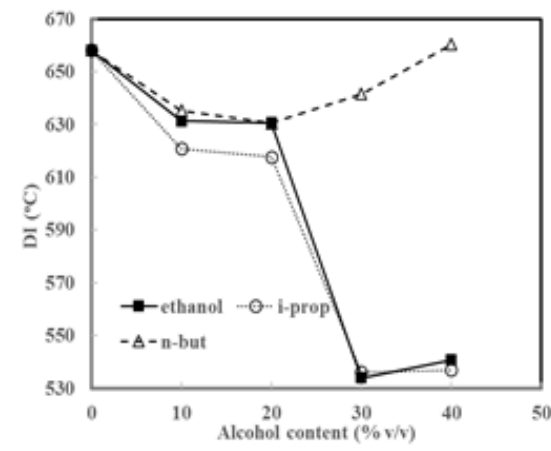

Figure 4. Drivability Index versus composition of ethanol, $i$ propanol and $n$-butanol blends with gasoline.

\subsection{Reid vapor pressure}

The Reid vapor pressure (RVP) is the vapor pressure of a fuel in $\mathrm{kPa}$, measured at $37.8^{\circ} \mathrm{C}$ according to ASTMD-323. RVP of a fuel is related to engine cold and hot starting, vapor lock tendency, and gaseous emissions composition. Fig. 5 presents the RVP versus alcohol content for the studied gasoline+alcohol blends. The low value of the vapor pressure of the base gasoline (12.4 $\mathrm{kPa}$ ) is explained by its chemical composition: reduced content of light hydrocarbons (Table 1). The change of vapour pressure of different gasoline alcohol blends is shown in Table 4. It can be observed an initial raise of vapor pressure (for blends with up to $20 \% \mathrm{v} / \mathrm{v}$ ethanol and $i$-propanol, and up to $5 \% \mathrm{v} / \mathrm{v} n$-butanol) followed by a decrease. The greatest raise was noted for gasoline+ethanol blends, and the lowest for gasoline $+n$ butanol blends. The maximum value of RVP of gasoline $+n$-butanol blends was registered at the lower alcohol content (5\% v/v $n$-butanol). The behavior of gasoline $+i$-propanol blends is intermediate between gasoline+ethanol and gasoline $+n$-butanol blends, respectively. The qualitative behavior of gasoline+alcohol blends examined in this study is similar with results obtained for blends of commercial gasoline $[6,13,15]$.

The addition of alcohol to gasoline up to a certain concentration has the effect of RPV increasing, because intermolecular interactions are weaker in gasoline+alcohol blends, than in pure alcohols. Moreover, the addition of alcohols to gasoline raised the vapour pressure of the blend as a result of positive azeotropes formation.

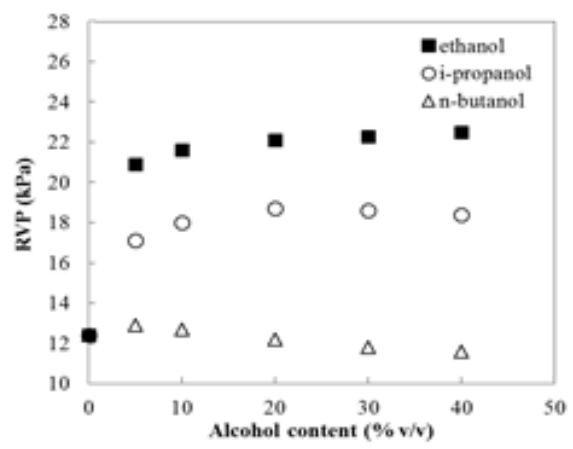

Figure 5. Reid vapor pressure versus composition of ethanol, $i$-propanol and $n$-butanol blends with gasoline.
Table 4. Vapor pressure change of gasoline alcohol blends.

\begin{tabular}{cccc}
\hline $\begin{array}{c}\text { Alcohol } \\
\text { content } \\
(\% \mathrm{v} / \mathrm{v})\end{array}$ & \multicolumn{3}{c}{ Vapor pressure change $(\mathrm{k} \mathrm{Pa})$} \\
\cline { 2 - 4 } & ethanol & $i$-propanol & $n$-butanol \\
\hline 0 & 0 & 0 & 0 \\
5 & 8.5 & 4.7 & 0.5 \\
10 & 9.2 & 5.6 & 0.3 \\
20 & 9.7 & 6.3 & -0.2 \\
30 & 9.9 & 6.2 & -0.6 \\
40 & 10.1 & 6.0 & -0.8 \\
100 & 3.6 & 0.2 & -10.3 \\
\hline
\end{tabular}

\section{Conclusions}

The presence of alcohols in gasoline modifies the distillation curve, a depression being registered as a result of positive azeotropes formation and the boiling point of the alcohol itself. The depression is similar for gasoline blends with ethanol or $i$-propanol, and much subtle for $n$-butanol blends. Alcohol addition to gasoline results in an initial increase of RVP, followed up by a decrease. The greatest raise was noted for gasoline+ethanol blends, and the lowest for gasoline $+n$ butanol blends. The maximum value of RVP of gasoline $+n$-butanol blends was registered at the lower alcohol content (5\% v/v $n$-butanol). The behavior of gasoline $+i$-propanol blends is intermediate between gasoline+ethanol and gasoline $+n$-butanol blends.

\section{Conflict of interest}

Authors declare no conflict of interest.

\section{References}

[1]. C. Jin, M. Yao, H. Liu, C.F. Lee, J. Ji, Progress in the production and application of $n$-butanol as a biofuel, Renew. Sustain. Energ. Rev. 15 (2011) 4080-4106. DOI: 10.1016/j.rser.2011.06.001

[2]. N. Qureshi, H.P. Blaschek, ABE production from corn: a recent economic evaluation, J. Ind. Microbiol. Biot. $27 \quad$ (2001) 292-7. DOI: $10.1038 /$ sj.jim.7000123

[3]. T.C. Ezji, N. Qureshi, H.P. Blaschek, Production of acetone, butanol and ethanol by Clostridium beijerinckii BA101 and in situ recovery by gas stripping, World J. Microb. Biot. 19 (2003) 595603. DOI: 10.1023/A:1025103011923

[4]. Y. Hirokawa, I. Suzuki, T. Hanai, Optimization of isopropanol production by engineered cyanobacteria with a synthetic metabolic pathway, J. Biosci. Bioeng. 119 (2015) 585-590. DOI: 10.1016/j.jbiosc.2014.10.005

[5]. S.B. Bankar, G. Jurgens, S.A. Survase, H. Ojamo, T. Granström, Genetic engineering of Clostridium acetobutylicum to enhance isopropanol-butanolethanol production with an integrated DNA technology approach, Renew. Energ. 83 (2015) 1076-10. DOI: 10.1016/j.renene.2015.05.052

[6]. E.V. Takeshita, R.V.P. Rezende, S.M.A. Guelli, G. Ulson de Souza, A.A. Ulson de Souza, Influence of solvent addition on the physicochemical properties of Brazilian gasoline, Fuel 87 (2008) 2168-77. DOI: 10.1016/j.fuel.2007.11.003 
[7]. L.M. Rodriguez-Anton, M. Hernadez-Campos, F. Sanz-Perez., Experimental determination of some physical properties of gasoline, ethanol and ETBE blends, Fuel 112 (2013) 178-184. DOI: 10.1016/j.fuel.2013.04.087

[8]. H.C. Aleme, L.M. Costa, P.J.S. Barbeira, Determination of the ethanol and specific gravity in gasoline by distillation curves and multivariate analysis, Talanta 78 (2009) 1422-8.

[9]. T.M. Foong, K.J. Morganti, M.J. Brear, G. Silva, Y. Yang, F.L. Dryer, The octane numbers of ethanol blended with gasoline and its surrogates, Fuel 115 (2014) 727-739. DOI: 10.1016/j.fuel.2013.07.105

[10]. L.M. Rodriguez-Anton, F. Gutierrez-Martin, C. Martinez-Arevalo, Experimental determination of some physical properties of gasoline, ethanol and ETBE ternary blends, Fuel 156 (2015) 81-86. DOI: 10.1016/j.fuel.2015.04.040

[11]. A.K. Thakur, A.K. Kaviti, R. Mehra, K.K.S. Mer, Progress in performance analysis of ethanolgasoline blends on SI engine, Renew. Sustain. Energ. Rev. 69 (2017) 324-340. DOI: $10.1016 /$ j.rser.2016.11.056

[12]. P. Iodice, A. Senatore, G. Langella, A. Amoresano, Effect of ethanol-gasoline blends on $\mathrm{CO}$ and $\mathrm{HC}$ emissions in last generation SI engines within the cold-start transient: An experimental investigation. Appl. Energ. $179 \quad$ (2016) 182-190. DOI: 10.1016/j.apenergy.2016.06.144

[13]. J.A. Pumphrey, J.I. Brand, W.A. Scheller, Vapour pressure measurements and prediction for alcoholgasoline blends, Fuel 79 (2000) 1405-11. DOI: 10.1016/S0016-2361(99)00284-7

[14]. A. Irimescu, Fuel conversion efficiency of a port injection engine fueled with gasoline isobutanol blends. Energy 36 (2011) 3030-3035. DOI: 10.1016/j.energy.2011.02.047

[15]. L.M. Rodriguez-Anton, F. Gutierrez-Martin, Y. Doce, Physical properties of gasoline, isobutanol and ETBE binary blends in comparison with gasoline ethanol blends, Fuel 166 (2016) 73-8. DOI: 10.1016/j.fuel.2015.10.106

[16]. T. Venugopal, A. Ramesh, Effective utilization of butanol along with gasoline in a spark ignition engine through a dual injection system. Appl. Therm. Eng. 59 (2013) 550-58. DOI: $10.1016 /$ j.applthermaleng.2013.06.026

[17]. T.J. Bruno, A. Wolk, A. Naydich, Compositionexplicit distillation curves for mixtures of gasoline with four-carbon alcohols (butanols), Energ. Fuel. 23 (2009) 2295-2306. DOI: 10.1021/ef801117c

[18]. M. Ezeldin, A. M. Masaad, M. J. A. Abualreish, C. Y. Ishak, The role of isopropylalcohol in the properties of Sudanese reformat gasoline, Orient. J. Chem. 33 (2017) 2085-9.

[19]. T.J. Bruno, L.S. Ott, T.M. Lovestead, M.L. Huber, The composition-explicit distillation curve technique: relating chemical analysis and physical properties of complex fluids, J. Chromatogr. A 1217 (2010) 2703-15. DOI: 10.1016/j.chroma.2009.11.030.

[20]. B. Murachman, D. Pranantyo, E.S. Putra, Study of gasohol as alternative fuel for gasoline substitution: characteristics and performances, Int. J. Renew. Energ. 3 (2014) 175-183.

[21]. A.B. Hadler, L.S. Ott, T.J. Bruno, Study of azeotropic mixtures with the advanced distillation curve approach, Fluid Phase Equilibr. 281 (2009) 49-59. DOI: 10.1016/j.fluid.2009.04.001

[22]. R. French, P. Malone, Phase equilibria of ethanol fuel blends, Fluid Phase Equilibr. 228-229 (2005) 27-40. DOI: 10.1016/j.fluid.2004.09.012

[23]. C. Jewitt, L. Gibbs, B. Evans, Gasoline Drivability Index, Ethanol Content and Cold-Start/Warm-Up Vehicle Performance, SAE Technical Paper (2005) 2005-01-3864.

Received: 09.10.2019

Received in revised form: 11.12.2019

Accepted: 12.12.2019 